\title{
Antioxidant status and lipid peroxidation activity in evaluating hepatocellular damage in children
}

\author{
K.A. Mahdy, ${ }^{1}$ A. Abd-El-Shaheed, ${ }^{2}$ M.E. Khadr ${ }^{3}$ and K.A.I. El-Shamy ${ }^{3}$
}

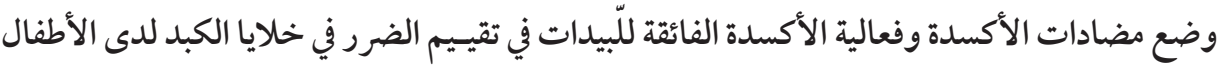

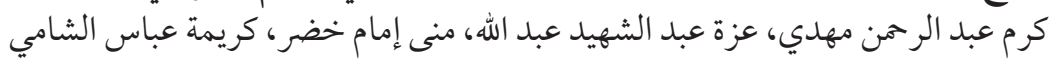

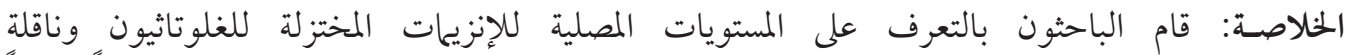

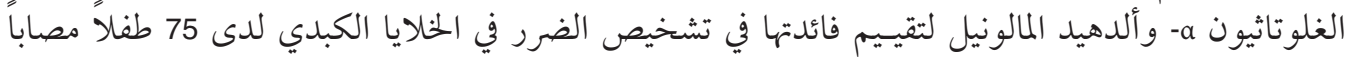

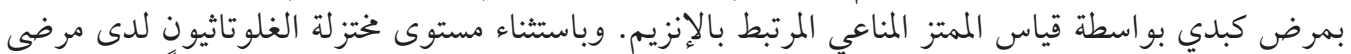

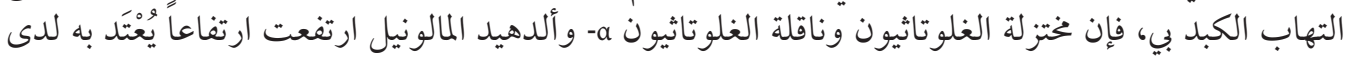

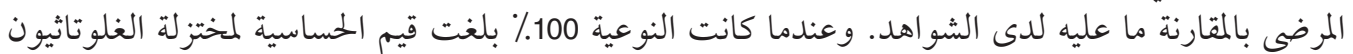

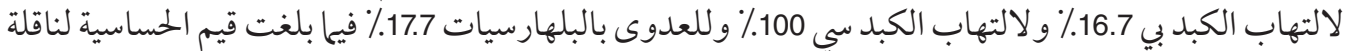

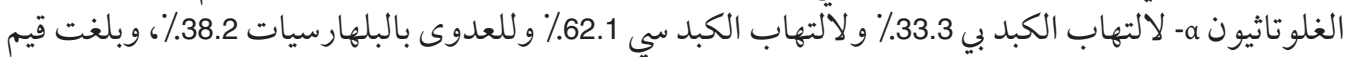

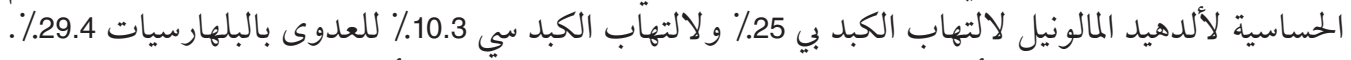

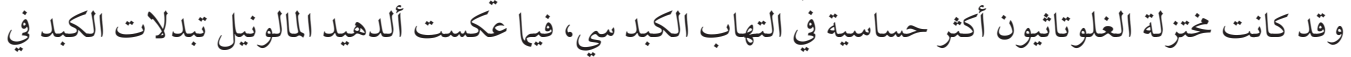

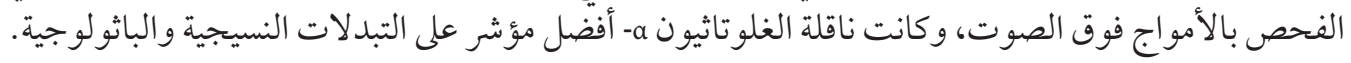

ABSTRACT Serum levels of glutathione reductase (GR), glutathione S-transferase- $\alpha$ (GST- $\alpha$ ) and malondialdehyde (MDA) were determined to evaluate their use in diagnosing hepatocellular damage in 75 children with liver disease. Except for level of GR in patients with HBV, GR, GST- $\alpha$ and MDA were raised significantly in patients compared with controls. At 100\% specificity, the sensitivity of the 3 markers for detecting hepatitis B virus, hepatitis $\mathrm{C}$ virus and schistosomiasis infection respectively were: $16.7 \%, 100.0 \%$ and $17.7 \%$ for GR; $33.3 \%, 62.1 \%$ and $38.2 \%$ for GST- $\alpha$; and $25.0 \%, 10.3 \%$ and $29.4 \%$ for MDA. GR was more sensitive in hepatitis $\mathrm{C}$ infection, while MDA reflected changes in liver ultrasound and GST- $\alpha$ was the best indicator for histopathological changes.

Rôle du statut antioxydant et du processus de péroxydation des lipides dans l'évaluation des lésions hépatocellulaires chez l'enfant

RÉSUMÉ Nous avons déterminé les taux sériques de glutathion-réductases (GR), d'a-glutathion-Stransférases ( $\alpha-G S T)$ et de malondialdéhyde (MDA) afin d'évaluer leur rôle dans le diagnostic des lésions hépatocellulaires chez 75 enfants souffrant d'une maladie hépatique. À l'exception du taux de GR chez les patients atteints du virus de l'hépatite B (VHB), les taux de GR, d'a-GST et de MDA étaient significativement plus élevés chez les malades que chez les témoins. Avec une spécificité de $100 \%$, la sensibilité des trois marqueurs pour le dépistage du VHB, du VHC et de la schistosomiase était respectivement de $16,7 \%, 100,0 \%$ et $17,7 \%$ pour les GR; de $33,3 \%, 62,1 \%$ et $38,2 \%$ pour les $\alpha$-GST ; et de 25,0 \%, 10,3\% et 29,4\% pour le MDA. Les GR étaient plus sensibles dans le cas de l'infection par le VHC, alors que le MDA témoignait de changements à l'échographie du foie et que les a-GST étaient le meilleur indicateur des changements histopathologiques.

${ }^{1}$ Department of Medical Biochemistry; ${ }^{2}$ Department of Child Health; ${ }^{3}$ Department of Medical Physiology, Medical Research Division, National Research Centre, Cairo, Egypt (Correspondence to K.A. Mahdy: Karammahdy@yahoo.com).

Received: 04/06/06; accepted: 28/01/07

المجلة الصحية لشرق المتوسط، منظمة الصحة العالمية، المجلد الخامس عشر، العلد ع، 9 +. 


\section{Introduction}

The liver is one of the main organs that generates free radicals in different pathological conditions [1]. Oxidative stress has been demonstrated to be implicated as a cause of hepatic fibrosis. Ito cells, the principal collagen-producing cells and the main storage sites of retinoids, have been demonstrated to be activated by free radicals as well as by malondialdehyde (MDA) [2].

Glutathione is a naturally occurring antioxidant that plays an important role against oxidative stress by reducing bisulfide linkage of proteins or by scavenging hydroperoxides and free radicals. Under normal conditions, more than $99.5 \%$ of total glutathione is in the reduced form (GSH) and less than $0.5 \%$ in the oxidized form (GSSG) which may be cytotoxic. Cells have 2 antioxidant mechanisms for ensuring a high GSH/GSSG ratio. First, in contrast to GSH, GSSG can be transported out of the cell. Second, GSSG can be reduced back to GSH by the enzyme glutathione reductase (GR) [3].

Glutathione S-transferase (GST) is a detoxification enzyme that catalyses the addition of glutathione to various xenobiotics [4]. GSTs are divided into 5 main classes: alpha, mu, pi, theta and zeta. GST- $\alpha$ is present in high concentration in hepatocyte cystosol [5]. The molecules most exposed to damage by free radicals are the polyunsaturated fatty acids of biological membranes. Deprived of 1 electron, they undergo lipid peroxidation, which can lead to cellular membrane damage. This is one of the mechanisms of hepatocyte injury. One of the lipid peroxidation products is MDA [1].

Currently, liver function tests such as alanine aminotransferase (ALT) and aspartate aminotransferase (AST) are used in the diagnosis and management of liver diseases. A disadvantage of these markers is that they are not distributed uniformly throughout the liver, the periportal concentration being greater than the centrilobular region [6]. In contrast, GST- $\alpha$ has been found to be equally distributed in both these regions [4]. Centrilobular hepatocytes are very susceptible to damage in a variety of clinical conditions including allograft rejection [7], viral hepatitis [8], chronic active hepatitis [9] and hepatotoxicity [10].

The aim of this study was to determine the serum levels of the antioxidant enzymes GR and GST- $\alpha$ and the lipid peroxidation product MAD to estimate their clinical usefulness in evaluating liver disease in children, and to correlate the changes of these markers with the changes of serum liver function tests and liver ultrasound and biopsy.

\section{Methods}

This work was done at the National Research Centre (NRC), Cairo, Egypt from 2001 to 2004, in accordance with the ethical principles of the NRC, in collaboration with the National Liver Institute of Menoufyia University, Egypt.

A total of 75 patients were enrolled in the study from the inpatient and outpatient clinics of the National Liver Institute. In addition 30 apparently healthy children with no liver disease were selected as controls from the paediatric clinic of the NRC. Medical history was obtained and clinical examination was carried out for all individuals. The participants were classified into the following groups:

- Hepatitis B virus (HBV) group: 12 patients (10 male; 2 female) (age range $3-15$ years). 
- Hepatitis C virus (HCV) group: 29 patients (22 male; 7 female) (age range 2-16 years)

- Schistosomiasis group: 34 patients (34 male; 0 female) (age range 6-15 years).

- Control group: 30 apparently healthy children (22 male; 8 female) (age range 3-15 years), with no history or clinical evidence of liver disease or any other diseases.

\section{Specimen collection}

Using aseptic techniques $5 \mathrm{~mL}$ of blood was taken from the patients and controls. Each blood sample was divided into 2 portions: 1 portion $(1.8 \mathrm{~mL})$ had sodium citrate anticoagulant $(3.8 \%)(0.02 \mathrm{~mL})$ added to obtain plasma; the other portion was allowed to clot. Serum was separated and stored at $-80{ }^{\circ} \mathrm{C}$ until tested, while the plasma sample was used immediately to measure prothrombin time and concentration.

\section{Serological analysis}

Hepatitis B surface antigen, hepatitis B core antibody IgM and hepatitis B core antibody IgG were measured using an enzymelinked immunosorbent assay (ELISA) kit (Dia-Sorin, Italy) by standard methods [11-13]. Anti-HCV was detected by a 3rd generation ELISA kit (Biochem Immunosystem, Canada) [14], while HCV-RNA extraction was carried out by reverse transcriptionpolymerasechainreaction[15]. Antischistosomal antibodies were measured with an indirect haemagglutination test kit (Fumoze, France) [16].

\section{Liver function tests}

Serum levels of AST, ALT, alkaline phosphatase (ALP), total and direct bilirubin, total protein, serum albumin and gamma glutamyl transpeptidase (GGT) were measured using enzymatic assay (Ektochem 750 XRC, Eastman Kodak, United States of America). Prothrombin time and concentration were also estimated in plasma [17].

\section{Antioxidants and free radicals markers}

ELISA kits were used for serum GR (Randox Laboratories, United Kingdom) [3] and serum GST- $\alpha$ (Biotrin, Ireland) [18]. Serum MDA was measured photometrically with a standard kit (Oxis Research International, United States of America) [19].

\section{Abdominal ultrasonography}

The size and echo pattern of the liver, the size of the spleen and presence of ascites or any other abnormalities in the abdomen of all patients were assessed using ultrasound (RT-X200 Prob 3.5 MHz convex, General Electric Company, United States of America).

\section{Liver biopsy}

For patients who gave informed consent and who had pyruvate carboxylase activity above $60 \%$ (26 patients), ultrasound-guided liver biopsy was done by true-cut needle followed by histopathological examination of the specimen using haematoxylin and eosin, orcein stain, Pert's stain and periodic acid Schiff stain and examined for staging and grading, according to the methods of Ishak et al. [20].

\section{Statistical analysis}

The data obtained were presented as means and standard errors. The difference between 2 groups was calculated using unpaired $t$ test, while the difference between more than 2 groups was calculated using the $F$-test [1-way analysis of variance (ANOVA)]. Correlation of variables was tested by the 
Pearson test. The analysis was made using SPSS, version 10 . Sensitivity, specificity and cut-off values were calculated using the standard equations according to Sox et al. [21].

\section{Results}

Patients with chronic liver diseases were divided into 3 groups according to the etiology: 12 patients with HBV, 29 with $\mathrm{HCV}$ infection and 34 with schistosomiasis. Mean age was 10.8 [standard deviation (SD) 1.0] years, $11.5(\mathrm{SD} 0.6)$ years and 11.8 (SD 1.5) years respectively. The control group was 30 sex-matched children with normal livers with a mean age of 10.5 (SD 0.5) years.

The mean serum levels of GR, GST- $\alpha$ and MDA for patients with HBV, HCV and schistosomiasis were significantly higher than in the control group. This was also true for each patient group separately (HBV, $\mathrm{HCV}$ and schistosomiasis groups) (Table 1). The highest level for GR was observed in $\mathrm{HCV}$ patients.

Liver function tests for the HBV, HCV, schistosomiasis and control groups are presented in Table 2. Except for total protein, the levels of all the measured parameters (AST, ALT, ALP, total bilirubin, direct bilirubin, albumin, GGT and prothrombin concentration) were significantly raised in HBV and HCV patients $(P<0.05)$. AST, ALT and prothrombin were raised in the schistosomiasis patients.

Using Pearson correlation between the studied markers and liver function tests, the GST- $\alpha$ level showed a significant correlation with serum ALT $(r=0.239, P=0.039)$ and the MDA level showed a significant correlation with total bilirubin $(r=0.233, P$ $=0.044)$ and with direct bilirubin $(r=0.294$, $P=0.011$ ) (not tabulated).

On correlating the serum levels of the GR, GST- $\alpha$ and MDA with the liver ultrasound findings presented in Table 3, using ANOVA, serum MDA level showed a significant increase in relation to findings of coarse texture with periportal/periseptal inflammation $(F=3.268, P=0.007)$ (not tabulated).

On correlating the serum levels of the 3 markers with the liver ultrasound findings using ANOVA, the serum MDA level showed a significant increase in relation to findings of coarse texture with periportal/periseptal inflammation $(F=3.268, P$ $=0.007$ ) (not tabulated).

Pearson correlation between serum levels of GR, GST- $\alpha$ and MDA with histopathological scoring (Table 4) revealed a significant correlation between GST- $\alpha$ with portal

\begin{tabular}{|c|c|c|c|c|c|}
\hline \multirow[t]{2}{*}{ Marker } & \multicolumn{5}{|c|}{ Mean (SE) level } \\
\hline & $\begin{array}{l}\text { Control } \\
(n=30)\end{array}$ & $\begin{array}{c}\text { HBV } \\
(n=12)\end{array}$ & $\begin{array}{c}\text { HCV } \\
(n=29)\end{array}$ & $\begin{array}{c}\text { Schist } \\
(n=34)\end{array}$ & $\begin{array}{c}\text { Total } \\
(n=75)\end{array}$ \\
\hline$\overline{\mathrm{GR}}(\mathrm{U} / \mathrm{L})$ & $11.1(0.3)$ & $10.7(0.6)$ & $28.3(5.4)^{\star, a}$ & $13.8(1.1)^{\star}$ & $18.9(2.3)^{\star}$ \\
\hline GST- $\alpha(\mu \mathrm{g} / \mathrm{L})$ & $12.4(0.3)$ & $15.5(0.9)^{\star}$ & $20.5(1.6)^{*}$ & $18.3(1.1)^{*}$ & $18.7(0.8)^{\star}$ \\
\hline MDA $(\mu \mathrm{M})$ & $2.7(0.07)$ & $3.3(0.2)^{\star}$ & $3.2(0.04)^{*}$ & $3.3(0.02)^{*}$ & $3.3(0.06)^{*}$ \\
\hline
\end{tabular}

${ }^{*}$ Significant difference compared with control group $(P<0.05)$.

a Significant difference compared with HBV or HCV groups $(P<0.05)$.

$H B V=$ hepatitis $B$ virus; $H C V=$ hepatitis $C$ virus; Schist $=$ schistosomiasis.

$G R=$ glutathione reductase, $G S T-\alpha=$ glutathione $S$-transferase $-\alpha ; M D A=$ malondialdhyde .

$S E=$ standard error.

المجلة الصحية لشرق المتوسط، منظمة الصحة العالمية، المجلد الخنامس عشر، العدد ع، 9 +. 
inflammation $(r=0.565, P=0.003)$, periportal/periseptal inflammation $(r=0.590$, $P=0.002)$ and histological activity index $(r$ $=0.578, P=0.002)$ (not tabulated).

Scatter diagrams of the 3 biochemical markers in the 3 different groups are presented in Figures 1, 2 and 3. The horizontal lines represent the cut-off values of the markers (mean $+2 \mathrm{SD}$ of control). The sensi- tivity and specificity of each maker were also calculated. The sensitivity of GR for diagnosing HCV patients was $100 \%$, while in HBV and schistosomiasis the sensitivity levels were $16.7 \%$ and $17.7 \%$ respectively at specificity level $93.3 \%$. For GST- $\alpha$, the sensitivity levels were $33.3 \%, 62.1 \%$ and $38.2 \%$ for $\mathrm{HCB}, \mathrm{HCV}$ and schistosomiasis. The MDA sensitivity level was $25.0 \%$ for $\mathrm{HBV}, 10.3 \%$ for $\mathrm{HCV}$

\begin{tabular}{|c|c|c|c|c|c|}
\hline \multirow[t]{2}{*}{ Liver function test } & \multicolumn{5}{|c|}{ Mean (SE) level } \\
\hline & $\begin{array}{l}\text { Control } \\
(n=30)\end{array}$ & $\begin{array}{c}\text { HBV } \\
(n=12)\end{array}$ & $\begin{array}{c}\text { HCV } \\
(n=29)\end{array}$ & $\begin{array}{l}\text { Schist } \\
(n=34)\end{array}$ & $\begin{array}{c}\text { Total } \\
(n=75)\end{array}$ \\
\hline$\overline{\mathrm{AST}}(\mathrm{U} / \mathrm{L})$ & $18.4(0.7)$ & $71.2(10.8)^{\star}$ & $120.0(21.8)^{\star}$ & $44.4(3.8)^{\star}$ & $77.9(9.6)^{\star}$ \\
\hline $\mathrm{ALT}(\mathrm{U} / \mathrm{L})$ & $20.5(0.9)$ & $72.6(12.4)^{\star}$ & $107.0(28.1)^{\star}$ & $38.0(3.4)^{\star}$ & $70.4(11.6)^{*}$ \\
\hline ALP (U/L) & $74.3(9.4)$ & $214.0(41.2)^{\star}$ & $165.028 .9)^{\star}$ & $77.0(5.6)$ & $133.0(14.9)^{*}$ \\
\hline Total bilirubin (mg/dL) & $0.8(0.02)$ & $1.8(0.2)^{*}$ & $1.3(0.1)^{\star}$ & $0.9(0.02)$ & $1.2(0.08)^{*}$ \\
\hline Direct bilirubin (mg/dL) & $0.16(0.02)$ & $1.3(0.2)^{\star}$ & $0.6(0.1)^{\star}$ & $0.2(0.02)$ & $0.5(0.07)^{*}$ \\
\hline Total protein (g/dL) & $6.9(0.1)$ & $6.8(0.2)$ & $6.7(0.1)$ & $7.1(0.1)$ & $6.9(0.08)$ \\
\hline Albumin (g/dL) & $4.0(0.02)$ & $3.5(0.2)^{\star}$ & $3.6(0.1)^{\star}$ & $3.8(0.02)$ & $3.7(0.06)^{*}$ \\
\hline GGT (U/L) & $26.0(2.1)$ & $54.0(16.0)^{*}$ & $59.9(11.1)^{*}$ & $36.0(4.4)$ & $48.2(0.05)^{*}$ \\
\hline Prothrombin (\%) & $93.0(1.3)$ & $69.4(6.0)^{\star}$ & $65.6(2.5)^{*}$ & $75.0(1.9)^{\star}$ & $70.6(0.02)^{\star}$ \\
\hline
\end{tabular}

${ }^{*}$ Significant difference compared with control group $(P<0.05)$.

$A S T=$ aspartate aminotransferase; $A L T=$ alanine aminotransferase; $A L P=$ alkaline phosphatase; $G G T=$ gamma glutamyl transpeptidase.

$H B V=$ hepatitis $B$ virus; $H C V=$ hepatitis $C$ virus; Schist $=$ schistosomiasis .

$S E=$ standard error.

\begin{tabular}{|c|c|c|c|c|c|c|c|c|}
\hline \multirow[t]{2}{*}{ Liver ultrasound finding } & \multicolumn{2}{|c|}{$\begin{array}{c}\text { HBV } \\
(n=12)\end{array}$} & \multicolumn{2}{|c|}{$\begin{array}{c}\mathrm{HCV} \\
(n=29)\end{array}$} & \multicolumn{2}{|c|}{$\begin{array}{l}\text { Schist } \\
(n=34)\end{array}$} & \multicolumn{2}{|c|}{$\begin{array}{c}\text { Total } \\
(n=75)\end{array}$} \\
\hline & No. & $\%$ & No. & $\%$ & No. & $\%$ & No. & $\%$ \\
\hline Hepatomegaly & 2 & 16.7 & 8 & 27.6 & 3 & 8.8 & 13 & 17.3 \\
\hline Shrunken liver & 1 & 8.3 & 1 & 3.9 & 0 & 0 & 2 & 2.7 \\
\hline $\begin{array}{l}\text { Periportal/periseptal } \\
\text { inflammation }\end{array}$ & 0 & 0 & 0 & 0 & 25 & 73.5 & 25 & 33.3 \\
\hline Diffuse pathology & 4 & 33.3 & 8 & 27.6 & 0 & 0 & 12 & 16.0 \\
\hline $\begin{array}{l}\text { Inflammation + diffuse } \\
\text { pathology }\end{array}$ & 1 & 8.3 & 0 & 0 & 3 & 8.8 & 4 & 5.3 \\
\hline Coarse texture & 4 & 33.3 & 10 & 34.5 & 0 & 0 & 14 & 18.7 \\
\hline $\begin{array}{l}\text { Diffuse pathology + coarse } \\
\text { texture }\end{array}$ & 0 & 0 & 2 & 6.9 & 3 & 8.8 & 5 & 6.7 \\
\hline Ascites & 10 & 83.3 & 25 & 86.2 & 25 & 73.5 & 60 & 80.0 \\
\hline Splenomegaly & 7 & 58.3 & 19 & 65.5 & 31 & 91.2 & 57 & 76.0 \\
\hline
\end{tabular}

$H B V=$ hepatitis $B$ virus; $H C V=$ hepatitis $C$ virus; Schist $=$ schistosomiasis. 
Eastern Mediterranean Health Journal, Vol. 15, No. 4, 2009

\begin{tabular}{llccc}
\hline \multicolumn{3}{l}{ Table 4 Histopathology scoring of the study children with liver disease } \\
\hline Histopathology finding & \multicolumn{3}{c}{ Mean (SE) histopathology score } \\
& $\begin{array}{c}\text { HBV } \\
(\boldsymbol{n}=\mathbf{5})\end{array}$ & $\begin{array}{c}\text { HCV } \\
(\boldsymbol{n}=\mathbf{1 3})\end{array}$ & $\begin{array}{c}\text { Schist } \\
(\boldsymbol{n}=\mathbf{8})\end{array}$ & $\begin{array}{c}\text { Total } \\
(\boldsymbol{n}=\mathbf{2 6})\end{array}$ \\
\hline $\begin{array}{l}\text { Portal inflammation } \\
\text { Periportal/periseptal }\end{array}$ & $1.6(0.2)$ & $1.3(0.2)$ & $2.1(0.4)$ & $1.7(0.2)$ \\
inflammation & $1.6(0.2)$ & $1.3(0.2)$ & $2.1(0.4)$ & $1.6(0.2)$ \\
Confluent necrosis & $0.4(0.2)$ & $0.8(0.9)$ & $1.0(0.5)$ & $0.8(0.3)$ \\
Spotty necrosis & $2.2(0.4)$ & $2.0(0.2)$ & $1.8(0.2)$ & $2.0(0.2)$ \\
Histological activity index & $5.8(1.0)$ & $5.6(0.8)$ & $7.0(1.1)$ & $6.1(0.5)$ \\
Fibrotic score & $4.8(0.7)$ & $5.6(0.5)$ & $3.9(0.7)$ & $4.0(0.4)$ \\
\hline
\end{tabular}

$H B V=$ hepatitis $B$ virus; $H C V=$ hepatitis $C$ virus; Schist $=$ schistosomiasis.

$S E=$ standard error.

and $29.4 \%$ for patients with schistosomiasis at a specificity level of $100 \%$.

\section{Discussion}

Both liver fibrosis and cirrhosis formation are multifactorial processes, and possible mechanisms leading to those diseases have not been yet clarified. Increasing evidence points to free-radical damage as an important contributor to the diseases $[22,23]$. Several host mechanisms are in place to neutralize the harmful effect of free radicals; these include a system of nutritional and endogenous enzymatic antioxidant defences that generally restrain the production of free radicals and prevent oxidant stress and subsequent tissue damage [24]. The body's key antioxidant and protectant is GSH, rather than GSSG, which may be cytotoxic. GR is responsible for maintaining $\mathrm{GSH}$ in the reduced form by catalysing the reduction of GSSG to GSH [3].

In the present study, serum levels of GR were significantly increased in HBV-, $\mathrm{HCV}$ - and schistosomiasis-infected patients compared with the control group. The highest elevation of GR was observed in HCV patients. Its sensitivity to diagnose $\mathrm{HCV}$ patients was $100 \%$, while in $\mathrm{HBV}$ and schistosomiasis the sensitivity levels were $16.7 \%$ and $17.7 \%$ respectively, at a specificity level of $93.3 \%$. These results are in accordance with the findings of previous studies [25-27] that GR was highly specific for GSSG and could be used in the detection of liver injury. So the increased activity of GR in our study could be explained by the fact that the increased production of reactive oxygen metabolites might be actively scavenged by GSH, resulting in the formation of GSSG, which is rapidly converted to GSH by GR.

We observed a significant increase in GST- $\alpha$ level in the 3 groups of patients compared with the control group. At a specificity level of $100 \%$, the sensitivity level was $33.3 \%$ for $\mathrm{HBV}, 62.1 \%$ for $\mathrm{HCV}$ and $38.2 \%$ for patients with schistosomiasis. The activity of GST $-\alpha$ has been shown to rise by oxygen radical to detoxify the toxic metabolites from lipid peroxidation caused during oxidative stress [28]. GST- $\alpha$ was significantly correlated with portal inflammation, periportal/periseptal inflammation and histologic activity index from histopathological examination. These results are in accordance with Beckett and Hayes [29], who found that the GST- $\alpha$ level correlated better with histological

المجلة الصحية لشرق المتوسط، منظمة الصحة العالمية، المجلد الخامس عشر، العلدد ع، 9 . ب 


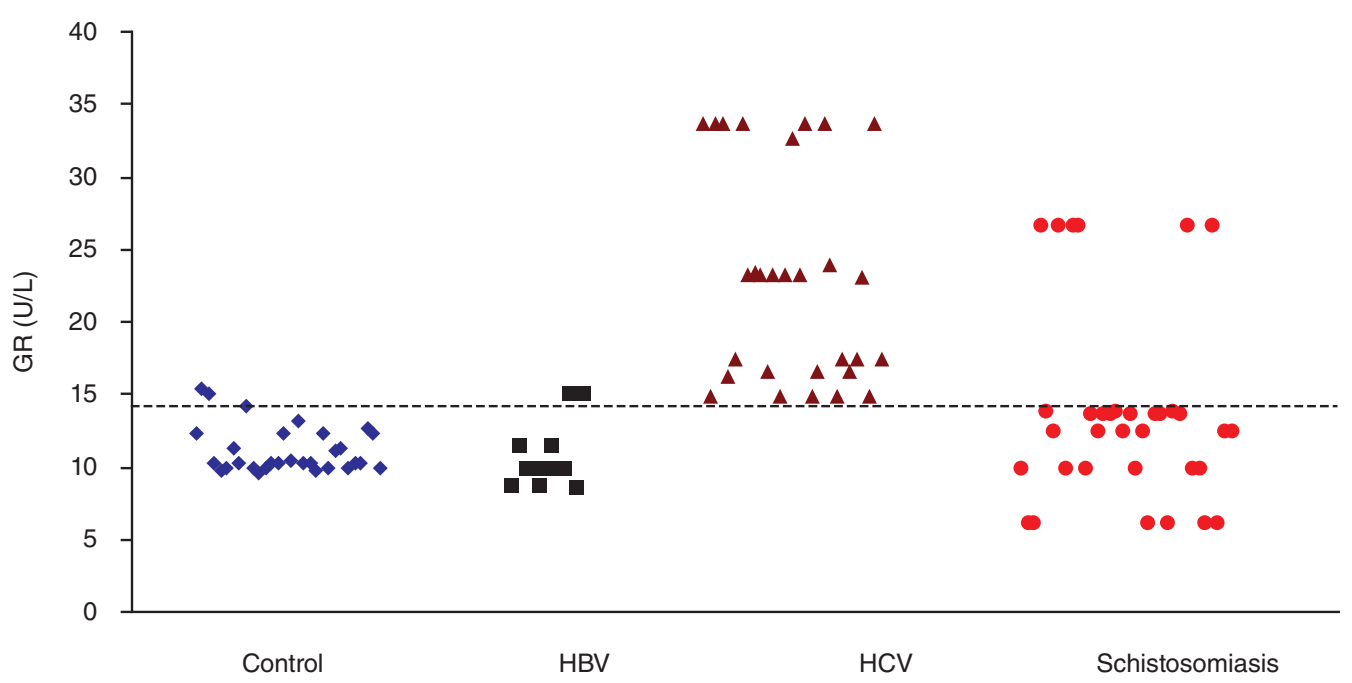

Figure 1 Scatter diagram of glutathione reductase (GR) level. The horizontal line represents the cut-off value of $14.3 \mathrm{U} / \mathrm{L}$ (mean +2 SD of controls). Sensitivity is $16.7 \%, 100 \%$ and $17.7 \%$ for patients with hepatitis B virus (HBV), hepatitis C virus (HCV) and schistosomiasis respectively at a specificity level of $93.3 \%$.

abnormalities. Others have concluded that the measurement of GST- $\alpha$ in the serum or plasma is probably the most sensitive biochemical test available for monitoring and reflecting the changes in hepatocellular injury [30]. Since we obtained a positive significant correlation between serum ALT and GST- $\alpha$ among our patients, we suggest that the association of plasma GST- $\alpha$ with ALT may improve the biochemical assessment of liver damage.

Regarding the changes induced in the levels of serum MDA, there was a significant increase in its level in the studied groups of patients compared to the control group. The MDA sensitivity level was $25 \%$ for the HBV group, $10.3 \%$ for the $\mathrm{HCV}$ group and $29.4 \%$ for patients with schistosomiasis at a specificity level of $100 \%$. The results indicate significant changes in the antioxidant capacity of cirrhotic tissue, which leads to enhanced action of oxygen radicals, leading to lipid peroxidation.

Lebensztein et al. reported elevated MDA levels in children with chronic hepatitis B [31], while Abd El-Ghaffar et al. reported the same significant elevation of MDA levels in chronic hepatitis $\mathrm{C}$ patients before and after interferon- $\alpha$ therapy [1]. These findings concur with our findings of a significant elevation of MDA levels in HBV- and HCV-infected patients, as well as in patients with schistosomiasis, but with a low sensitivity rate. Moreover, we found a significant positive correlation between serum MDA and total and direct bilirubin, as well as a significant elevation in of MDA in patients with coarse texture with periportal/periseptal inflammation findings by ultrasonic examination of the liver.

Our results are in accordance with the finding of Socha et al. who found that raised

المجلة الصحية لشرق المتوسط، منظمة الصحة العالمية، المجلد الخامس عشر، العدد ع، 9 + · 


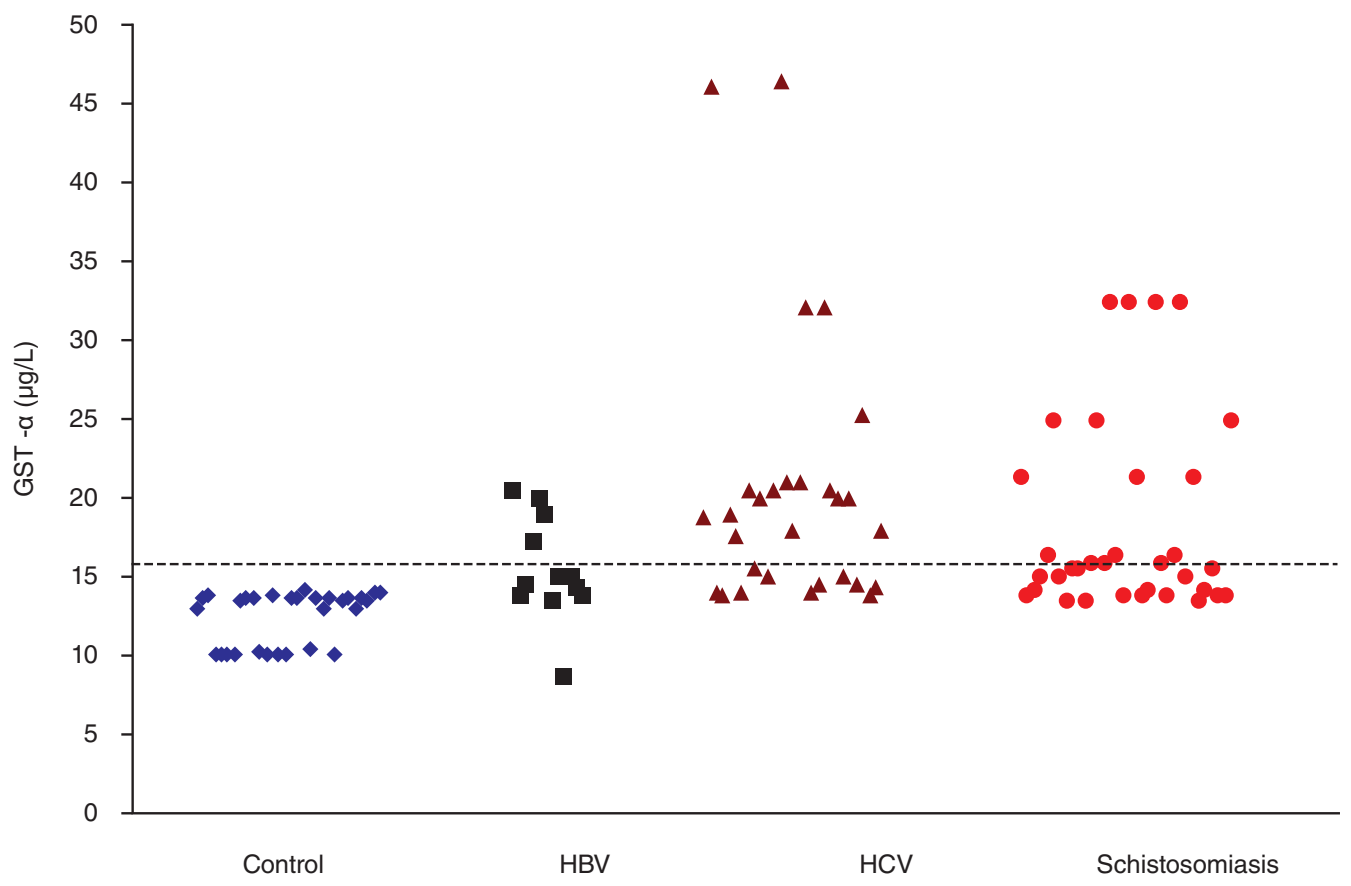

Figure 2 Scatter diagram of glutathione S-transferase- $\alpha$ level (GST). The horizontal line represents the cut-off value of $15.8 \mu \mathrm{g} / \mathrm{L}$ (mean $+2 \mathrm{SD}$ of controls). Sensitivity is $33.3 \%$, $62.1 \%$ and $38.2 \%$ for patients with hepatitis $B$ virus (HBV), hepatitis C virus (HCV) and schistosomiasis respectively at a specificity level of $100 \%$.

MDA in liver disease may be attributed to disturbances in blood circulation and oxygenation, e.g. ischaemia, which in turn cause lipid peroxidation and subsequently increase in MDA concentration [32]. Another hypothesis has been raised by Farinati et al. that hepatitis-related liver damage is characterized by increased iron storage [33], which elicits a free-radical mediated peroxidation via the Fenton reaction [34]. Hydroxyl radicals may react by either hydroxylation or hydrogen abstraction, setting off free-radical chain reactions that subsequently increases MDA concentration $[26,34]$.

To sum up, our results agree with other studies that have shown increased MDA level and changes in activities of GSHrelated enzymes [27]. These findings indicate that the glutathione antioxidant system is imbalanced in hepatocellular damage, and they support the hypothesis that oxidative stress plays an important role in the development of these liver diseases. One critical question is whether this abnormality is one of the causes of these liver diseases or is just one of the consequences of their progression. This question remains to be answered by additional research.

In conclusion, serum GR, GST- $\alpha$ and MDA measurements are useful in monitoring hepatocellular damage in children. GR levels are a more sensitive indicator for $\mathrm{HCV}$ infection, MDA reflects the changes in liver

المجلة الصحية لشرق المتو سط، منظمة الصحة العالمية، المجلد الخامس عشر، العدد ع، 9 . ب 


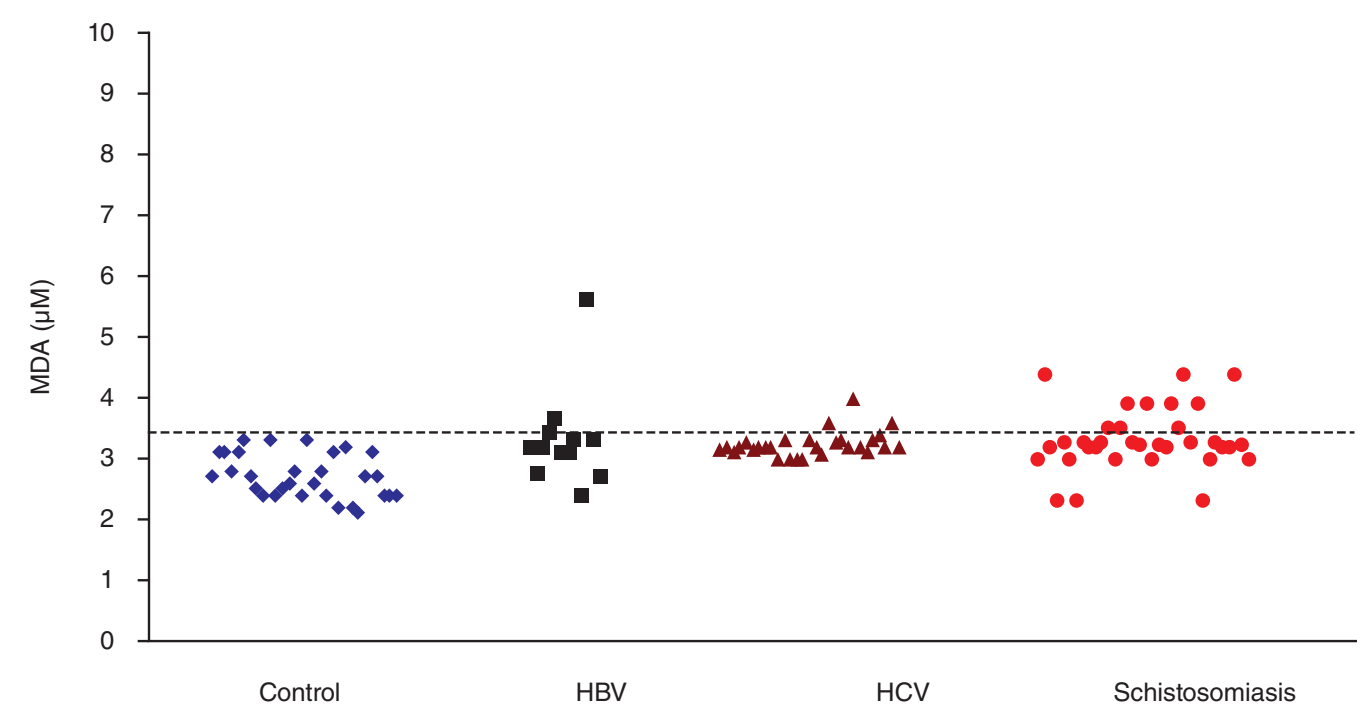

Figure 3 Scatter diagram of malondialdehyde level (MDA). The horizontal line represents the cut-off value of $3.43 \mu \mathrm{M}$ (mean + 2SD of controls). Sensitivity is $25.0 \%, 10.3 \%$ and $29.4 \%$ for patients with hepatitis $B$ virus (HBV), hepatitis $C$ virus (HCV) and schistosomiasis respectively at a specificity level of $100 \%$.

ultrasonography, while GST- $\alpha$ is the best indicator for histopathological changes.

\section{Acknowledgements}

The authors sincerely thank Dr Mostafa Sera from the National Liver Institute for his kind help in collecting the blood samples from the patients in this study.

This study was funded by the National Research Centre research plan 2001-04, projects $5 / 4 / 5$ and $5 / 5 / 5$, in collaboration with the National Liver Institute of Menoufyia University, Egypt.

\section{References}

1. Abd El-Ghaffar Y, Foud HH, Eid A. Effect of interferon-a therapy on oxidative stress in hepatitis $\mathrm{C}$ virus infection. Arab journal of laboratory medicine, 1999, 25(3):34554.

2. Omoya $\mathrm{T}$ et al. Suppressive effects of retinoids on oxidative stress in rat liver mitochondria and Ito cells. Gastroenterology, 1998, 114(4):A1317 [Abstract].

3. Goldberg DM, Spooner RJ. Glutathione reductase. In: Bergmeyen HV, ed. Meth- ods of enzymatic analysis, 3th ed. New York, Academic Press, 1983.

4. Sundberg AGM et al. Immunohistochemical localization of alpha and $\mathrm{Pi}$ class glutathione transferases in normal human tissues. Pharmacology and toxicology, 1993, 72:321-31.

5. Knapen MF et al. A marker for hepatocellular damage. Lancet, 2000, 355(52):1463-4. 
6. Kew MC. Serum aminotransferase concentration as evidence of hepatocellular damage. Lancet, 2000, 355:591-2.

7. Trull AK et al. Serum $\alpha$-glutathione $S$ transferase: a sensitive marker of hepatocellular damage associated with acute liver allograft rejection. Transplantation, 1999, 58(12):1345-51.

8. Nelson DR et al. $\alpha$-glutathione S-transferase as a marker of hepatocellular damage in chronic hepatitis $C$ virus infection. American journal of clinical pathology, 1995, 104:193-8.

9. Norris $S$ et al. Serum $\alpha-G S T$ as an early indicator of disease relapse following treatment withdrawal in autoimmune CAH. Hepatology, 1994, 20(4):2.

10. Murray JM et al. Indocyanine green clearance and hepatic function during and after prolonged anaesthesia: comparison of halothane with isoflurane. British journal of anaesthesia, 1992, 68:168-71.

11. Boniolo A, Davis A, Metteja R. The use of enzyme linked immunosorbent assay for screening hybridoma antibodies against hepatitis B surface antigen. Journal of immunological methods, 1982, 49:1-7.

12. Tedder RS, Wilson-Croome R. IgMantibody response to the hepatitis $\mathrm{B}$ core antigen in acute and chronic hepatitis $B$. Journal of hygiene, 1981, 86:163.

13. Hoofangle JH, Gerety RJ, Barker LF. Antibody to hepatitis $B$ virus core in man. Lancet, 1973, 2:869.

14. Alter HJ. Transfusion associated non-A non-B hepatitis. The first decade. In: Zuckermann AJ, ed. Viral hepatitis and liver disease. New York, Alan R Liss, 1988:537-42.

15. Ravaggi A, Primi D, Caraini E. Direct RT-PCR amplification of HCV RNA from human serum. PCR methods and applications, 1992, 1:291-2.
16. Hoshino S, Camargo ME, Da Silva LC. Standardization of a haemagglutination test for schistosomiasis with formalintreated erythrocytes. American journal of tropical medicine and hygiene, 1980, 19(3):463-70.

17. Poller L. Laboratory control of anticoagulant therapy. Seminars in thrombosis and hemostasis, 1986, 12:13-9.

18. Rees GW et al. Validation of an enzyme immunoassay for the detection of $\alpha$-glutathione S-transferase in human serum. Annals of clinical biochemistry, 1995, (32):575-83.

19. Esterbauer $H$, Schaur RJ, Zollner $H$. Chemistry and biochemistry of 4-hydroxynonenal, malonaldehyde and related aldehydes. Free radical biology and medicine, 1991, 11:81-128.

20. Ishak $\mathrm{K}$ et al. Histological grading and staging of chronic hepatitis. Journal of hepatology, 1995, 22:696-9.

21. Sox $\mathrm{HC}$ et al. Medical decision making. London, Butterworth, 1989:67-146.

22. Jungst $C$ et al. Oxidative damage is increased in human liver tissue adjacent to hepatocellular carcinoma. Hepatology, 2004, 39:1663-72.

23. Balasubramanian S, Kowdley KV. Effect of alcohol on viral hepatitis and other forms of liver dysfunction. Clinics in liver disease, 2005, 9(1):83-101.

24. Halliwell B. Free radical, antioxidants and human diseases: curiosity, cause or consequence? Lancet, 1994, 344:721-4.

25. Young IS, Woodside JV. Antioxidants in health and disease. Journal of clinical pathology, 2001, 54(3):176-86.

26. Koruk $M$ et al. Oxidative stress and enzymatic antioxidant status in patients with nonalcoholic steatohepatitis. Annals of clinical and laboratory science, 2004, 34(1):57-62. 
27. Hassan L et al. Time course of antioxidant enzyme activities in liver transplant recipients. Transplantation proceedings, 2005, 37(9):3932-5.

28. Czeczot $\mathrm{H}$ et al. Glutathione and GSHdependent enzymes in patients with liver cirrhosis and hepatocellular carcinoma. Acta biochimica polonica, 2006, 53(1):237-41.

29. Beckett GJ, Hayes JD. Glutathione Stransferase: biochemical applications. Advances in clinical chemistry, 1993, 30:281-380.

30. Sidlova K et al. Serum a-glutathione Stransferase as a sensitive marker of hepatocellular damage in patients with cystic fibrosis. Physiological research, 2003, 52:361-3.

31. Lebensztejn DM et al. The role of free oxygen radicals in children with chronic viral hepatitis. B. Roczniki Akademii Medycznej w Bialymstoku, 1995, 40(3):66772.

32. Socha P, Rujner J, Socha J. Rola rodników tlenowych i antyoksydantów w patogenezie przewlekłych zapaleń wątroby [The role of oxygen radicals and their antioxidants in pathogenesis of chronic hepatitis]. Pediatria polska, 1992, 67(Suppl. 1-2):139-44.

33. Farinati $F$, Cardin R, Marie N. Iron storage, lipid peroxidation and glutathione turnover in chronic anti-HCV positive hepatitis. Journal of hepatology, 1995, 22:449-56.

34. Blake DR, Allen DR, Lunec J. Free radicals in biological system: a review oriented to inflammatory processes. British medical bulletin, 1987, 43:371-85.

Picturing health: 35 years of photojournalism at WHO

WHO Archives holds many black and white photographs showing the work done in various health-related professions by people from all parts of the world.

This exhibit offers a selection of photostories taken by photographers from the 1950 s to the 1980 s. These images illustrate health programmes established by governments and by WHO. The pictures presented in the photo galleries under 26 topics are accompanied by their original captions.

The exhibit can be seen at: http://www.who.int/features/2009/photoarchives/en/index.html 